\title{
Online Religious Learning during the Covid-19 Pandemic: Teachers Practices in Central and East Java, Yogyakarta, and Bali, Indonesia
}

\author{
Agus Iswanto ${ }^{1}$, Arif Gunawan Santoso ${ }^{2}$, Umi Muzayanah ${ }^{3}$, and Siti Muawanah ${ }^{4}$ \\ \{agus.iswanto83@gmail.com¹, abuazka79@gmail.com²,umimoza78@gmail.com³, \\ analitbang@gmail.com $\left.{ }^{4}\right\}$
}

Balai Penelitian dan Pengembangan Agama Semarang, Badan Litbang dan Diklat Kementerian Agama, Semarang $1,2,3,4$

\begin{abstract}
This article deals with the implementation of Islamic learning in public schools and general learning in Islamic religious education institutions, namely madrassas during pandemic era. This article will contribute to the empirical knowledge about online learning practices in Islamic Religious Education at schools and madrasa. This research was conducted by online survey method with non-probability sampling in Central and East Java, Yogyakarta, and Bali, Indonesia. This research found that the most widely used application in the learning process was Whatsapp,. This research also found that the biggest obstacle in online learning is internet infrastucture; the network is unevenly distributed to all areas and most students were in difficulties in reaching the internet. In addition, this reaseach also revealed another big problem in online religious learning, namely the inability of this type of learning to provide students with character education which is the main goal of religious education.
\end{abstract}

Keywords: Online religious Learning, Covid-19 Pandemic, Teacher Practices

\section{Introduction}

The Covid-19 pandemic has changed human life in all aspects [1]; economic [2,3], social, pshycological [4], tourism [5,6], politics [7], religion [8], and education (including religious education) [9-11]. It also also leads people to respond it variously. In terms of education, Indonesian government responds the pandemic by suggesting educational institutions to conduct teaching-learning process in distance, what the so-called as online learning.

There have been some researches conducted on education since the pandemic outbreaks, either education in global level or more specifically in Indonesia. The reseaches tried to portray education from different angels, such as the capacity of the country and its people to run online learning [13,14], students' perspectives on online learning [15], teacher's perspectives on online learning[16], and parents' responses who were often stressful because of online learning [17]. In addition, there were some researches which uncovered some obstacles in this kind of learning [18].

Unfortunately, the aformentioned researches did not pay attention to religious education. They were not interested in describing how religion, especially Islamic religion, was taught and lernt in educational instutitions. Although we found some researches discussing about religious education, they were focusing more, and limiting their discussion on, the implementation of elearning on the Islamic education subject $[19,20]$ and the use of online and social media for teaching-learning process $[21,22]$; they have not discussed about the teachers' perspectives on the online learning yet. 
This article is discussing about the practic of Islamic education learning both in public schools and in madrasah during the Covid-19 pandemic era. The focus of the study was how the teachers of Islamic Education subject, from elementary schools to senior high schools, taught their students in distance. So did madrasah teachers from the same levels. The article is dealing with the followong issues: teachers' and students' readiness, platforms used in online learning process, subject materials, gained learning target, and obstacles on the online learning process. In addition, this article is also offering a solution to the online learning problems for Islamic education in distance with what the so-called as "hybrid learning."

\section{Method}

This is a quantitative study whose main instrument was questionaire. The instrument was distributed to the respondents in the form of google form. Because the researchers found difficulties in accessing definite population at the beginning, the reseach, therefore, applied nonprobability sampling technique with convenience sampling. It is a kind of sampling which respondents are voluntarily filling out the questionaires. In addition, the fact that internet network could not reach remote areas becomes another reason to apply the such sampling technique[23].

The population of this study was all teachers at madrasah (MI, MTs, and MA) and the tachers of Islamic Education subjects at public schools from the four provinces (Central and East Java, Yogyakarta, and Bali). The four provinces were selected considering the number of teachers from three different categories: high (Central and East Java), middle (Yogyakarta), and low (Bali).

The total sample was 17,661 teachers consisting of 12,229 techers at madrasas and 5,432 teachers of Islamic education subject at public schools. Since it was an online survey, the respondents were the teachers who had internet access, had android based cellular/computer, and were intentionally participated in the survey. The figure 1 pictures pupulation and sample distrubution of the survey.

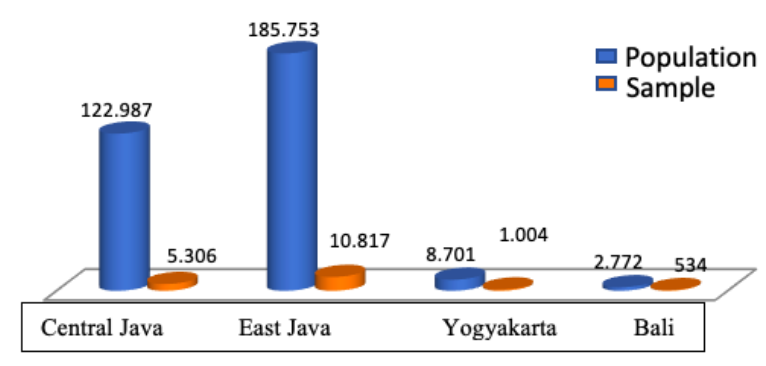

Figure 1. The population and sample distribution .

Source: Kementerian Agama in Central Java, East Java, Yogyakarta, and Bali

In addition to considering the representativeness of the four provinces, the population can also be described according to some categories: employment status, certification, and educational levels. The description according to the categories is presented by table 1

Table 1. Population and sample distribution 


\begin{tabular}{lrrrr}
\hline \multicolumn{1}{c}{ Category } & \multicolumn{1}{l}{ Total } & \multicolumn{1}{l}{$\%$} & \multicolumn{1}{l}{ Total } & \multicolumn{1}{c}{$\%$} \\
\hline Government Employees & 63.075 & $19,70 \%$ & 6.234 & $35,30 \%$ \\
Non Government Employees & 257.138 & $80,30 \%$ & 11.427 & $64,70 \%$ \\
Total & 320.213 & & 17.661 & \\
Certified teacher & 146.731 & $45,82 \%$ & 10506 & $59,49 \%$ \\
Non certified teacher & 173.482 & $54,18 \%$ & 7155 & $40,51 \%$ \\
Total & 320.213 & & 17.661 & \\
SD/MI & 168.929 & $52,76 \%$ & 9.120 & $51,64 \%$ \\
SMP/MTs & 98.933 & $30,90 \%$ & 5.818 & $32,94 \%$ \\
SMA/SMK/MA & 52.351 & $16,35 \%$ & 2.723 & $15,42 \%$ \\
\hline
\end{tabular}

In order to portray online Islamic learning at madrasahs and public shools, the main variables are teachers' understanding of online learning process and their competency to perfom the process. The indicators of the variables are shown by table 2 .

Table 2. Variables and indicators of the research

\section{Teachers' Competency of Understanding \\ Teachers' ability in Using Digital Tools}

Online Learning

1. Understanding students' preparation

2. Understanding parents'preparation

3. Understanding supporting facilities

4. Understaning useful media for online learning process
1. Ability of using various media

2. Ability of using

3. Ability of creating online learning media (self-independency and cooperation)

4. Ability of conducting online learning evalution

In terms of data analysis, the researchers conducted two main steps. The data were firstly described and then interpreted according to perspectives on digital learning, literacy education, and religious education

One of the research weaknesses is due to the fact that it was conducted during the Covid-19 pandemic when people are strongly recommended to make physical and social distance so that it was impossible to be regulary conducted. In addition, the lack portion for students' perspectives is another weaknesses because it focused more on teachers' perspectives and their practices on online learning-teaching process

\section{Result and Discussion}

\subsection{The Readiness of Teachers and Students}

An essential issue to consider before conducting online learning is teachers and students readiness because the matter is dealing with psychological aspect. 


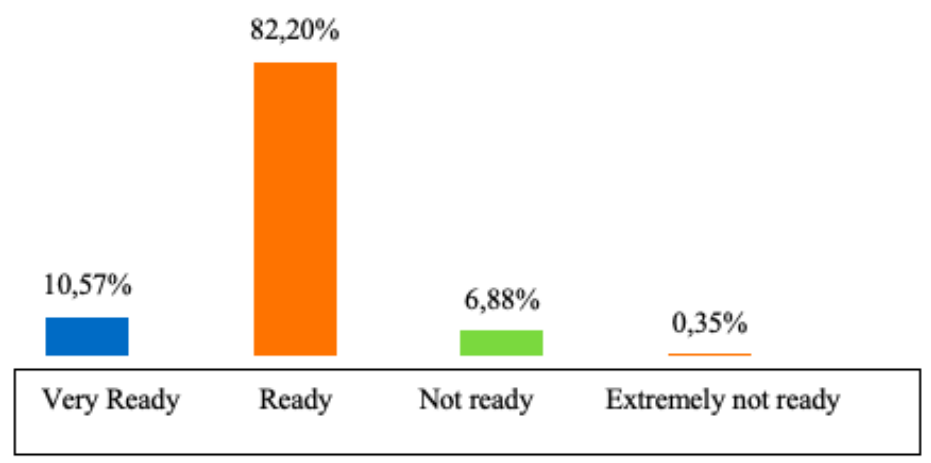

Figur 2. Teachers' readiness for online learning teaching process

The picture 2 shows that the majority of madrasah and Islamic education teachers $(82.20 \%)$ claim to be ready and $10,57 \%$ very ready for online learning. However, we can also see that there are teachers who claim to be not ready for online learning. We can also see how readiness of madrasah and Islamic education teachers for the online learning process by province. The teachers' readiness is described by figure 3 .

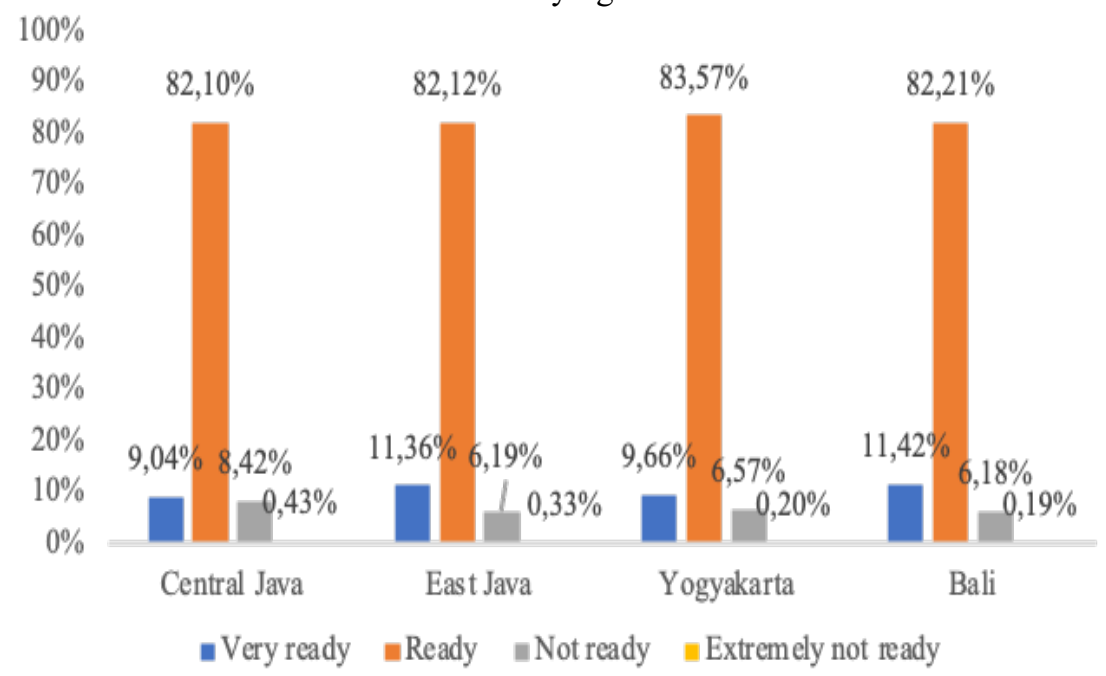

Figur 3. Teachers' readiness for online learning teaching process by province

Apart from teachers, students' readiness for online learning is important in achieving learning goals. Students readiness for online learning based on the teacher's perspective can be described in Figure 4. 


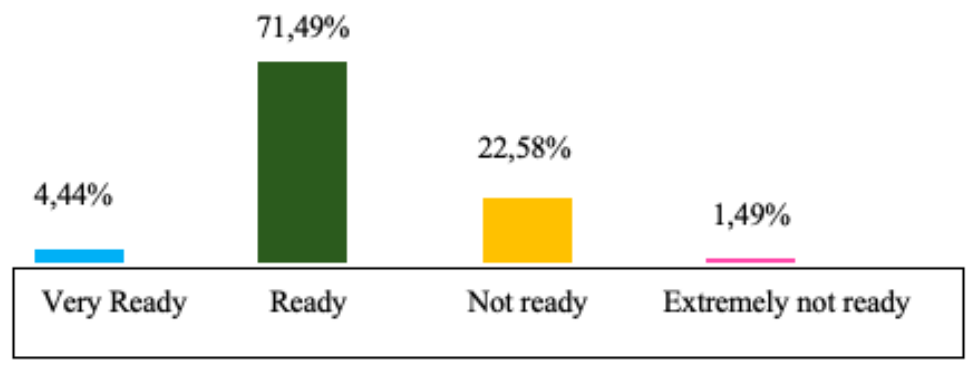

Figure 4. Students' Readiness for online learning teaching process

The picture 4 shows that the majority of teachers say that students are ready to take part in online learning. However, there were quite a number of students who were not ready $(22.58 \%)$ and extremely not ready (1.49\%) for online learning. Then how is the readiness of students for online learning in each province. It is described by figure 5 .

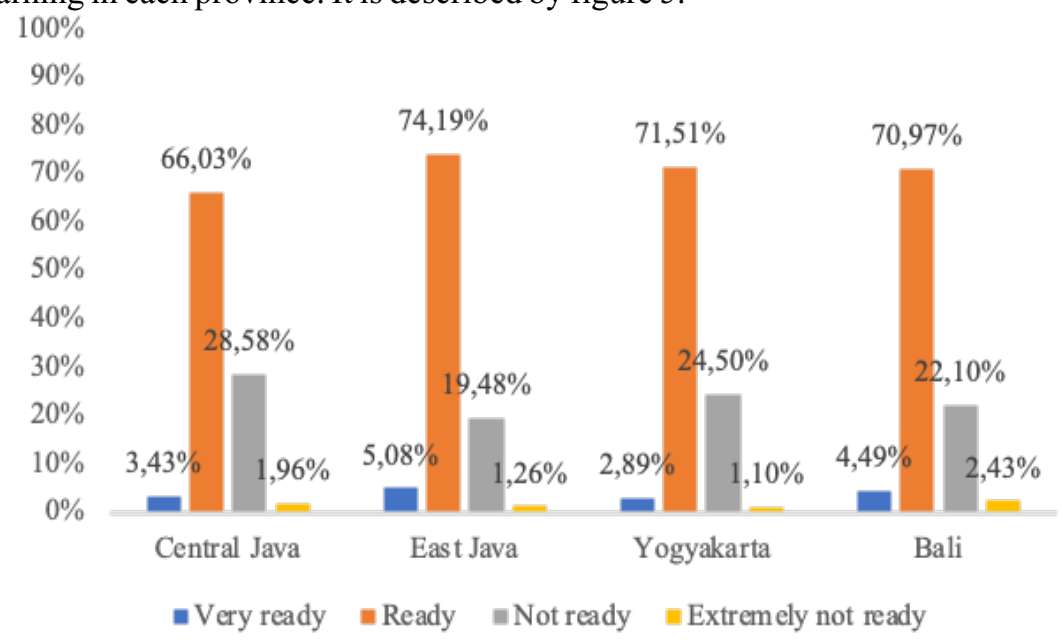

Figure 5. Students' readiness for online learning teaching process by province

Although figure 2, 3, 4, and 5 could not describe teachers and students readiness perfectly, they illustrate their psychological readiness for the process. These four figures convince the readers that teachers and students are enthusiastic for online learning.

Other considerable aspects in performing online learning are knowledge and skills about the process. The online learning teaching process require digital technology. Therefore, skilled human resources are very essentials. Unfortunately, not all teachers are well-informed nor wellskilled with digital equipments and its programs because the majority (71,60 percent) were not trained. Only 28,40 percent of them were trained for digital technology. The fact confirms previous information that teachers' readiness for online learning teaching process tends to be more psychologically than technically. 


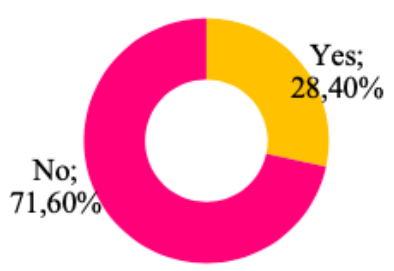

Figure 6. Teachers' Participation in Computer and Technology Training Program for Teaching Learning

\subsection{Digital Devices for Online Learning}

Figure 7 and 8 show aplications which teachers often used during online learnig process. Figure 7 illustrates the answers of teachers at madrasahs while the other (figure 8) is the answers of Islamic education teachers at public schools. From the figure, we can see that Whatsap, Google form, and Google Classroom are three the most frequently used applications. They become the most popular because they are easy-used programs. Teachers can easily share materials with students using Whatsap.

One important thing to note here is the portion of E-learning (figure 7). Althoug this is a program officially launched by Ministry of Religious Affairs for teachers at madrasahs it is less popular among them. It only reaches 6.31 percent.

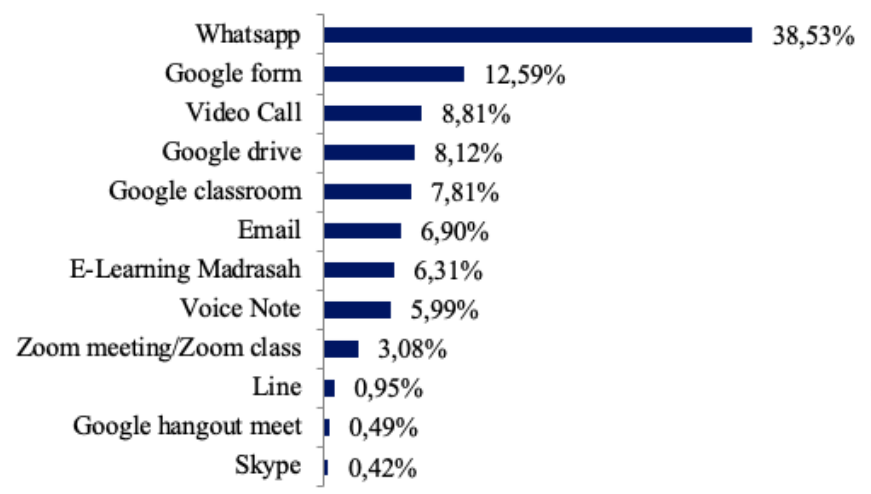

Figure 7. Frequently used aplications among teachers at madrasahs during pandemic 


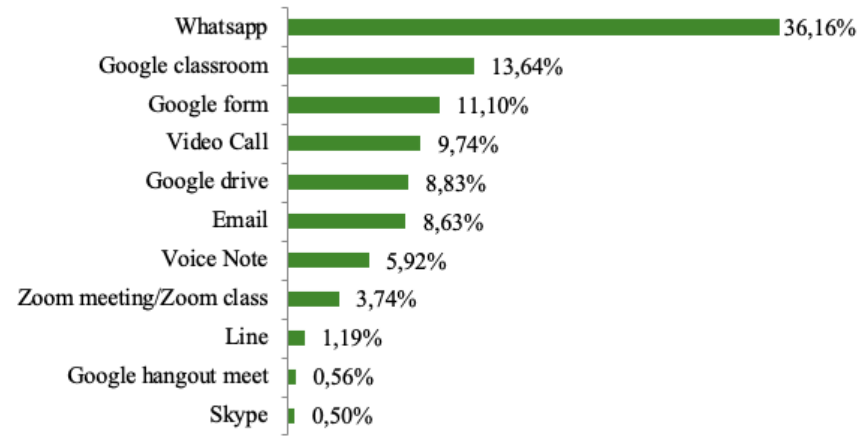

Figure 8. Frequently used applications among teachers of Islamic education at public schools during pandemic

This condition is not significantly different from that before pendemic (see figure 9). Figure 7 and 8 tell readers about the aplications used by the teachers at the time (during pandemic era). The fact that the majority of the teachers have not been given yet training in digital technology explaines the trend. If they were well-trained in digital technology, they should have been more familiar with various digital application, they should have used more interactive ones.

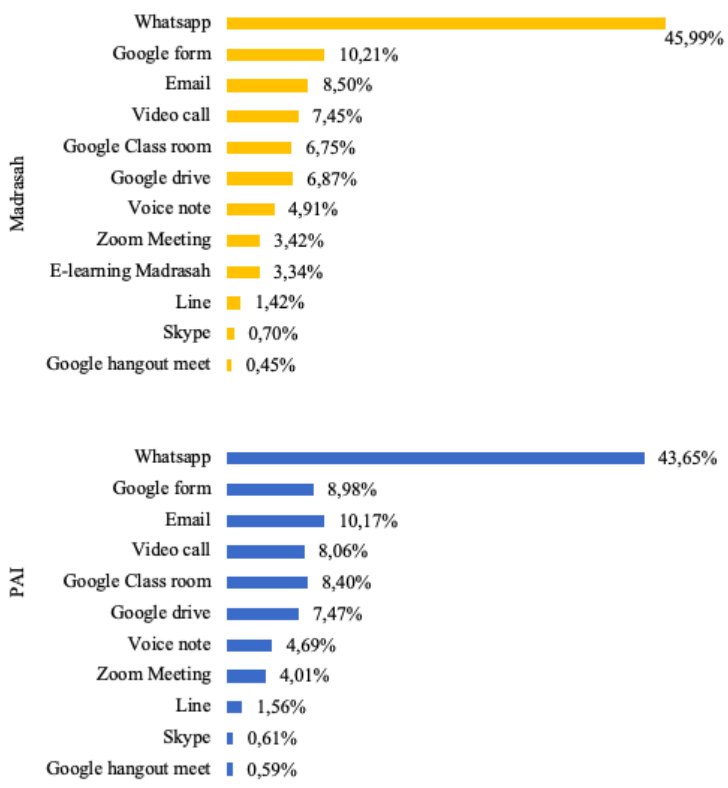

Figure 9. Frequently used aplications among teachers before Covid-19 pandemics

\subsection{Material Subjects in Online Learning}

Although the majority of teachers did not participate in digital technology training programs, most of them provided students with materials themselves in addition to downloading 
them from internet. Most materials are files and pictures. This is a recognized advantage in teaching learning process during emergency period because they were more independent in preparing materials (see figure 10)

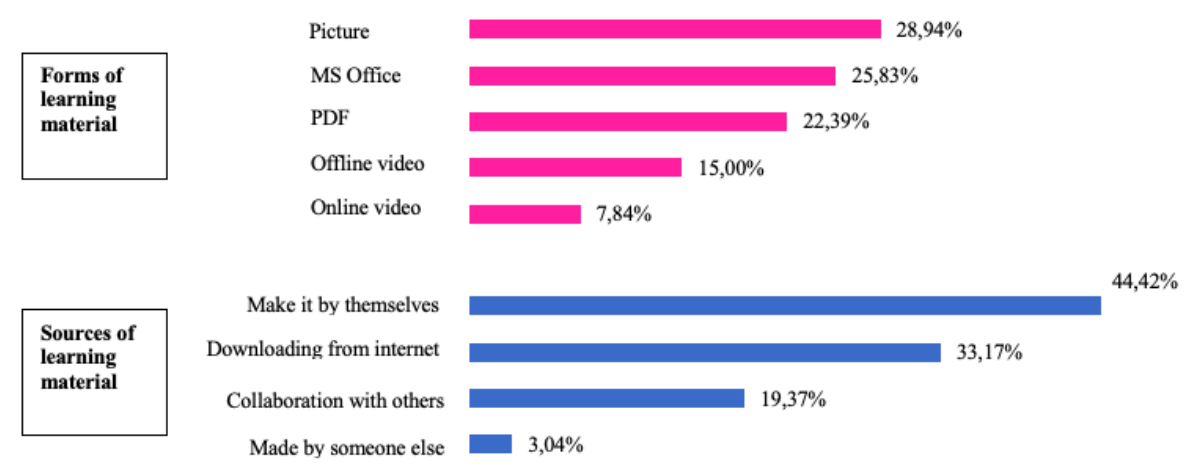

Figure 10. Sources and forms of online learning materials during Covid-19 pandemics

\subsection{The Challenges of Online Teaching-Learning Process}

Knowing the challenges of the online teaching learning process is important in order to make the process in the future (new normal) better. The biggest challenge in the online teaching learning process is the low signal, limited internet quota, and insufficient electronic devices (celluler phones, laptop, and computers) (see figure 11). Those devices are highly siginificant because the online teaching learning process is impossibly conducted without them.

According to figure 11, skill in operating digital divices is the lightest challenge. It means that both students and teachers are able to use the devices properly. The figure can also be interpretated that device ownership does not positively relate to the skill. Those who do not have celluler phones are not automatically unable to operate the devices. To be more specific, although it is only a cellular phone available for all family members, all of them could be very digital literate. Therefore, the strongest challenge in online teaching learning process is proper internet infrastructure and family finance.

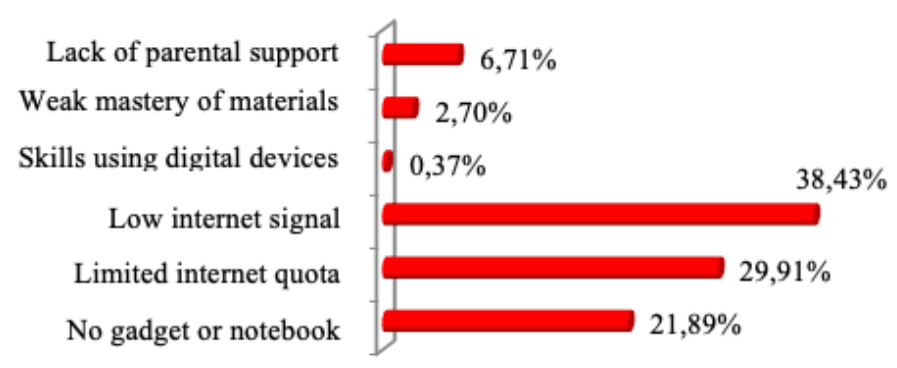

Figure 11. Constraints in Online Learning in the Covid-19 Pandemic Period

As it was mentioned previously[24], online teaching learning process demands high cost for providing appropriate internet quota. This research results in the similar findings in which the strongest challenge of online teaching learning process, in teachers' opinion, is inappropriate 
interet signal as well as its limited quota. It is udoubted that Indonesia is weak in terms of internet infrastucture[25].

\subsection{Discussion \\ 3.6.1 Parents' Roles in Islamic Education}

Another crucial finding of the research needs to be futher discussed is materials for Islamic education subject. Considering the materials given to the students during pandemic period, the online teaching learning process tends to focus more on cognitive aspect. It pays less attention to affective and motoric ones. It means that the teaching learning process does not succeed in providing students with proper spiritual nor social competences according to Islamic teachings. On one side, it is an obvious problem in teaching Islam in a distance but it gives parents invaluable chance to take their roles on the other side. They can pay more attention to their children, take a part in building their characters as well as teaching them about Islam more intensely because they have more time to make a much better familial relationship.

\subsubsection{Weaknesses of Online Religious Education}

It has been previously discussed that religious education is insufficiently taught in distance, because it needs to pay more attention on spiritual and social competences than cognitive one. Therefore, religious education needs another alternative.

If teaching technological information literacy, even basic literacy, can be conducted in distance, so can religious and character education. They are not properly taught in distance because it will result in imperfect outcome. Therefore, we need another type of learning which is the so-called as "hybrid learning" or "blended learning". By this kind of learning the teachers can select certain materials taught by distance and other materials given face to face.

\subsubsection{Online Learning and Digital Literacy}

Another important finding needs to be seriously discussed is using digital devices in online learning process. It is mentioned before that the majority of teachers used Whatsap, Google forms, and Google Classroom as their media for online learning. In addition to them, there are a number platforms which are more interactive for learning. Such a condition is due to the fact that most teachers are not well-informed nor well-skilled in digital technology for online learning. Moreover, they were inadequately trained in operating the devices and programs.

Considering such a fact, the most important problem is literacy. Online lerning can be conducted by using two kinds of literacy, namely digital literacy and information literay. Digital literacy means the skill of using digital devices for online elarning, while information literacy is the ability of searcing, evaluating, and using information (26). Both require infrastructure availability, adequate human resource capacity, and external supporting factors.

\section{Conclusion and Recomendation}

\subsection{Conclusion}

The teachers of Islamic Education subject at public schools as well as the teachers at madrasahs are really psychologically ready for online teaching learning process. In terms of the knowledge and skills, unfortunately, they are insufficienty ready because they have not been trained yet in digital technology for online teaching learning. The majority of the teachers use Whatsap and Google form which are less interactice for the process. Nevertheless, a number of them provide the materials themselves and downloading them from internet. The biggest problem of the kind of learning process is inadequate internet infrastructure as well as its limited quota. 


\subsection{Recomendation}

Since the online teaching learning process of Islamic education is inadequately paying attention to spiritual and social competences, the process should implement another better alternative. It is the so-called "hybrid learning" or "blended learning". In addition, parents are supposed to play their roles better.

Moreover, in order to make it more interactive, online learning needs to qualified digital literacy and information literacy. Therefore, well-trained teachers are a must.

\section{References}

[ADDIN Mendeley Bibliography CSL_BIBLIOGRAPHY 1]. Hiscott J, Alexandridi M, Muscolini M, Tassone E, Palermo E, Soultsioti M, et al. The global impact of the coronavirus pandemic. Cytokine Growth Factor Rev [Internet]. 2020;53(May):1-9. Available from: https://doi.org/10.1016/j.cytogfr.2020.05.010

[2]. Correia S, Luck S, Verner E. Pandemics Depress the Economy, Public Health Interventions Do Not: Evidence from the 1918 Flu [Internet]. SSRN Electronic Journal. 2020. Available from: https://ssrn.com/abstract $=3561560$

[3]. Fernandes N. Economic effects of coronavirus outbreak ( COVID-19) on the world economy Nuno Fernandes Full Professor of Finance IESE Business School Spain [Internet]. SSRN Electronic Journal. 2020. Available from: https://ssrn.com/abstract=3557504

[4]. Dubey S, Biswas P, Ghosh R, Chatterjee S, Dubey MJ, Chatterjee S, et al. Psychosocial impact of COVID-19. Diabetes Metab Syndr Clin Res Rev [Internet]. 2020;14(5):779-88. Available from: https://doi.org/10.1016/j.dsx.2020.05.035

[5]. Gössling S, Scott D, Hall CM. Pandemics, tourism and global change: a rapid assessment of COVID-19. J Sustain Tour [Internet]. 2020;0(0):1-20. Available from: https://doi.org/10.1080/09669582.2020.1758708

[6]. Karabulut G, Bilgin MH, Demir E, Doker AC. How Pandemics Affect Tourism: International Evidence [Internet]. SSRN Electronic Journal. 2020. Available from: https://ssrn.com/abstract $=3579530$

[7]. van Holm EJ, Monaghan J, Shahar DC, Messina J, Surprenant C. The Impact of Political Ideology on Concern and Behavior During COVID-19 [Internet]. SSRN Electronic Journal. 2020. Available from: https://ssrn.com/abstract=3573224

[8]. Bentzen JSi. In crisis, we pray: Religiosity and the Covid-19 pandemic. In: Wyplosz C, editor. Covid Economics: Vetted and Real-Time Papers. Geneva: The Centre for Economic Policy Research (CEPR) Press; 2020. p. 52-107.

[9]. Abidah A, Hidaayatullaah HN, Simamora RM, Fehabutar D, Mutakinati L. The Impact of Covid19 to Indonesian Education and Its Relation to the Philosophy of "Merdeka Belajar." Stud Philos Sci Educ [Internet]. 2020;1(1):38-49. Available from: https://ssrn.com/abstract=3557504

[10]. Cao W, Fang Z, Hou G, Han M, Xu X, Dong J. The psychological impact of the COVID-19 epidemic on college students in China Wenjun. Psychiatry Reserach. 2020;287(January):6.

[11]. Viner RM, Russell SJ, Croker H, Packer J, Ward J, Stansfield C, et al. School closure and management practices during coronavirus outbreaks including COVID-19: a rapid systematic review. Lancet child Adolesc Heal [Internet]. 2020;4(5):397-404. Available from: http://dx.doi.org/10.1016/S2352-4642(20)30095-X

[12]. Djalante R, Lassa J, Setiamarga D, Sudjatma A, Indrawan M, Haryanto B, et al. Review and analysis of current responses to COVID-19 in Indonesia: Period of January to March 2020. Prog Disaster Sci. 2020;6(100091):9.

[13]. Basilaia G, Kvavadze D. Transition to Online Education in Schools during a SARS-CoV-2 Coronavirus (COVID-19) Pandemic in Georgia. Pedagog Res. 2020;5(4).

[14]. Hoq MZ. E-Learning During the Period of Pandemic ( COVID-19 ) in the Kingdom of Saudi Arabia : An Empirical Study. Am J Educ Res. 2020;8(7):457-64. 
[15]. Agarwal S, Kaushik JS. Student's Perception of Online Learning during COVID Pandemic. Indian J Pediatr. 2020;87(7):554.

[16]. Djuanda U, Barat J, Aliyyah RR, Djuanda U, Barat J, Rachmadtullah R, et al. The Perceptions of Primary School Teachers of Online Learning during the COVID-19 Pandemic Period: A Case Study in Indonesia. 2020;7(2):90-109.

[17]. Susilowati E, Azzasyofia M. The Parents Stress Level in Facing Children Study From Home in the Early of Covid-19 Pandemic in Indonesia. 2020;2(3):1-12.

[18]. Anwar M, Khan A, Sultan K. The Barriers and Challanges Faced by Students in Online Education During Covid-19 Pandemic in Pakistan. Gomal Univ J Reserach. 2020;36(1):52-62.

[19]. Syahfitri R, Sari DP, Wahyuni A, Fatimah S, Setiawan HR. Implementasi E-Learning Pada Mata Pelajaran Pendidikan Agama Islam Di masa Pandemi Covid-19. Al-Ulum J Pendidik Islam. 2020;I(1):22.

[20]. Yusuf M, Hamdani, Siregar AP, Siregar FN. Implementasi Pendidikan Agama Islam di Masa Pandemi Covid-19. Maslahah J Pengabdi Masy. 2020;1(1):38-48.

[21]. Jaelani A, Fauzi H, Aisah H, Yulianti Q, Zaqiyah. Penggunaan Media Online dalam Proses Kegiatan Belajar Mengajar PAI di Masa Pandemi Covid-19 (Studi Pustaka dan Observasi Online). J Ika Ikat Alumni PGSD UNARS. 2020;8(1):17.

[22]. Muslimah. Peran Media Sosial dalam Pendidikan dan Pengajaran Agama Islam pada Masa Pandemi Covid 19. Aktual J Penelit Sos dan Keagamaan. 2020;10(Juni):40-59.

[23]. Fink A. How To Conduct Surveys, A Step By Step Guide. California: Sage Publications, Inc.; 2017. $225 \mathrm{p}$.

[24]. Demuyakor J. Coronavirus (COVID-19) and Online Learning in Higher Institutions of Education: A Survey of the Perceptions of Ghanaian International Students in China. Online J Commun Media Technol. 2020;10(3):9.

[25]. Lim M. Dis/Connection: The Co-evolution of Sociocultural and Material Infrastructures of the Internet in Indonesia. Indonesia. 2018;105(1):155-72.

[26]. Kidd TT, Keengwe J. Information Literacy in the Digital Age. Adult Learn Digit Age. 2010;218. 